\title{
JEHOAHAZ, KING OF ISRAEL, ACCORDING TO JOSEPHUS
}

CHRISTOPHER BEGG

Catholic University of America

\section{INTRODUCTION}

The Bible devotes a mere 11 verses $(2 \mathrm{Kgs} 13,1-9+22-23)$ to the 17-year reign of Jehoahaz of Israel. This short segment nevertheless evidences a variety of textual, compositional, redactional, chronological and historical problems '. In this essay I propose to study Josephus' account of Jehoahaz in Antiquitates Judaicae (=Ant.) $9.173-176^{2}$ in relation to its Biblical source as represented by the following major witnesses: MT (= BHS), the Codex Vaticanus $(=\mathrm{B})^{3}$ and the Lucianic $(=\mathrm{L})$ or Antiochene MSS ${ }^{4}$ of the LXX plus Targum Jonathan on the Former Prophets (= TJ) ${ }^{5}$. My comparison aims to answer the following questions: Which text-form(s) of 2 Kings 13 did Josephus have available in composing his account of Jehoahaz? How does he deal with the various problems posed by the Biblical source? Finally, has he introduced elements of his own into his retelling of the source story, and if so, for what purpose has he done so? My investigation of these questions in connection with the

' On these problems, see, in addition to the commentaries: D. J. MCCARTHY, «2 Kings 13,4- 6", Biblica 54 (1973) 409-410.

${ }^{2}$ I use the text and translation of H. ST. J. THACKERAY, et al. (eds.), Josephus, London - Cambridge, MA 1926-1965. Ant. 9.173-176 is found in Vol. VI, pp. 92-95, where the translation and notes are by $R$. MARCus.

${ }^{3}$ For this I use the text of A. E. Brooke, N. Mcl.ean, and H. ST. J. Thackeray, The Old Testament in Greek, II.II: I and II Kings, Cambridge 1930.

${ }^{4}$ For the text of L I use the edition of N. Fernández Marcos and J. R. Busto SAIz, El texto antioqueno de la biblia griega, II: I-2 Reyes, Madrid 1992. As we will be seeing, the $L$ text diverges rather notably from both MT and B in 2 Kings 13.

${ }^{5}$ I use the edition of TJ by A. SPERBER, The Bible in Aramaic II, Leiden 1959, and the translation of this by D. J. HARRINGTON and A. J. SAldarini, Targum Jonathan on the Former Prophets, Wilmington 1987. 
historian's treatment of Jehoahaz is intended as a small contribution to the much wider problem of "Josephus and the Bible".

\section{JEHOAHAZ' STORY RETOLD}

Jehoahaz is (re-)introduced ${ }^{6}$ in $2 \mathrm{Kgs} 13,1$ with a double chronological notice: acceding in the twenty-third year of Joash of Judah, Jehoahaz ruled seventeen years. The latter of these indications poses a problem in that according to $2 \mathrm{Kgs} 13,10$ Jehoahaz' son Joash succeeded his father in the thirty-seventh year ${ }^{7}$ of his Judean namesake, whereas tallying the chronological data of $13,1(23+17$ years) would place the Israelite Joash's accession in the fortieth regnal year of Joash of Judah. Josephus (9.173a) disposes of the difficulty by having I $\omega \alpha \zeta \zeta^{8}{ }^{8}$ accede in Joash's twenty-first (rather than twenty-third) year ${ }^{9}$.

$2 \mathrm{Kgs} \mathrm{13,2}$ pronounces an unqualified, stereotyped judgment on Jehoahaz:

He did what was evil in the sight of the Lord, and followed the sins of Jeroboam... which he made Israel to sin; he did not depart from them ${ }^{10}$.

\footnotetext{
6 Jehoahaz' succession is mentioned ( $2 \mathrm{Kgs} \mathrm{10,35b)}$ in passing as part of the closing notices for his father Jehu (10,32-36). Jehoahaz next resurfaces in 2 Kgs 13,1 following two extended chapters dealing with events in Judah, i.e. Athaliah's seizure of power there and eventual overthrow $(2 \mathrm{Kgs} \mathrm{11,1-20)}$ and the reign of the Davidid Joash who is installed in her place (12,1-21). In Josephus' presentation the sequence of material preceding his version of $2 \mathrm{Kgs} 13,1$ in 9.170 is somewhat different: he intersperses his conclusion for the reign of Jehu $(9.159-160 / / 2 \mathrm{Kgs} 10,32-36$, this ending up with mention of Jehoahaz' succession) between his accounts of the rise and fall of Athaliah (9.140-158) and the reign of the Judean Joash (9.161-172).

7 Thus MT and B L*. Other LXX MSS read 40, 36, and 39, see BHS.

8 Compare B I $\omega \alpha \chi \alpha \zeta, \mathrm{L} i \omega \alpha \chi \alpha \zeta \zeta$.

9 See M. Cogan and H. Tadmor, II Kings, Garden City, NY 1988, p. 143. Note that Josephus' subsequent chronology raises a problem of his own in that he dates, $9.177(2 \mathrm{Kgs} 13,10)$, the accession of Joash of Israel, following the seventeen year reign of his father Jehoahaz in the thirty-seventh year of Joash of Judah, whereas the figures he cites in $9.173(21+17)$ would place Joash's accession rather in his Judean namesake's thirty-eighth year; possibly, the discrepancy relates to the difference among the witnesses in the synchronism of 13,10 (see n. 7). On Josephus' monarchical chronology in relation to the Biblical one(s) in general, see E. R. THIELE, The Mysterious Numbers of the Hebrew Kings, Chicago 1951, pp. 204-227.
}

10 Biblical translations follow the RSV. 
Josephus begins $(9.173 b)$ his evaluation of the king with an attenuating remark:

although he was no imitator ( $\mu \iota \mu \eta \tau$ ' $\varsigma)$ " of his father...

This qualification concerning Jehoahaz' cultic depravity has no basis in the Biblical account as such ${ }^{12}$. It likely has in view the subsequent portrayal, common to both the Bible $(2 \mathrm{Kgs} \mathrm{13,4)}$ and Josephus (9.175) of Jehoahaz' imploring divine assistance in the face of Syrian aggression-something which his father Jehu is not discribed as doing in like circumstances, see $2 \mathrm{Kgs} \mathrm{10,33-34//} \mathrm{Ant.}$ 9.159-160a ${ }^{13}$. Having thus mitigated the Biblical censure of Jehoahaz, Josephus next proceeds nonetheless to cite a generalized version of

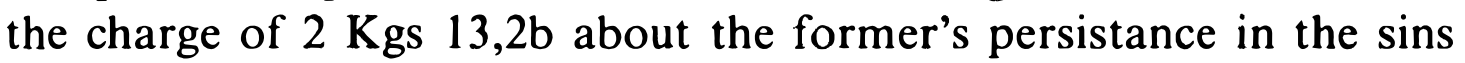
of Jeroboam:

... he committed as many impieties $(\dot{\alpha} \sigma \varepsilon \beta \eta \dot{\eta} \sigma \alpha \varsigma)$ as did the first

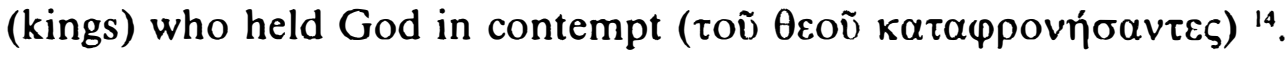

2 Kgs 13,3 recounts the divine response to Jehoahaz' impiety: in his anger against Israel, the Lord hands it over into the power of the Syrian rulers Hazael and Ben-Hadad. This notice is subsequently picked up in 13,7 which relates the drastic reduction of the Israelite

1 The terminology of "(non-)imitation " figures prominently in Josephus' versions of the royal judgment notices of Kings and Chronicles, see, e.g., Ant. 10.37: Manasseh “imitating ( $\mu \mu$ oú $\mu \varepsilon v 0 \varsigma)$ the lawless deeds of the Israelites..." 10.47: Amon «imitated $(\mu \iota \eta \eta \sigma \dot{\alpha} \mu \varepsilon v \sigma \zeta)$ the deeds of his father...". Cf. also Josephus' remark on Jehoahaz' own son Joash: "he was a good man and in no way like his father in character" (Ant. 9.178).

12 Rabbinic tradition likewise has nothing good to say of Jehoahaz (I owe this observation to Prof. L. H. Feldman).

${ }^{13}$ On the Josephan Jehu, see C. T. BEGG, "Josephus' Version of Jehu's Putsch (2 Kgs 8,25-10,36)", Antonianum 68 (1993) 450-484.

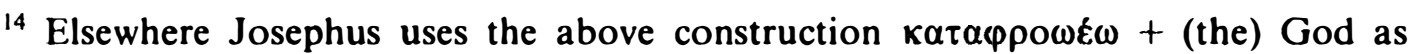
genitival object in Ant. 3.15 (the Israelites); 4.215 (men); 12.357 (Antiochus). Compare Ant. 1.43: Eve is misled by the serpent to "scorn the commandment of God"; 7.151:

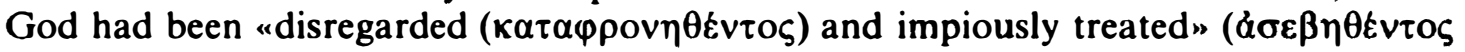
-note the collocation of the same two verbs used of Jehoahaz in 9.173 here) by David; 8.251: Rehoboam «showed disrespect for the worship of God»; 9.160: Jehu

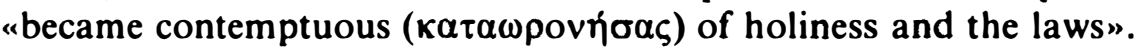


forces effected by the unnamed king of Syria ${ }^{15}$. Passing over the theological indication of $13,3^{16}$, Josephus (9.174) moves immediately to his version of 13,7 :

But the king of Syria humbled him ${ }^{17}$ and reduced his force $(\delta u v \alpha \dot{\mu} \varepsilon \omega \varsigma){ }^{18}$ from the very great one it was to ten thousand foot soldiers (o $\pi \lambda i \tau \alpha \varsigma, \mathrm{LXX} \pi \varepsilon \zeta \dot{\omega} v)$ and fifty horsemen ( $\pi \varepsilon v \tau \eta \dot{\eta} \kappa o v \tau \alpha$ i $\pi \pi \varepsilon i \bar{\zeta}$, $=\mathrm{LXX})^{19}$ when he marched against him and took from him many

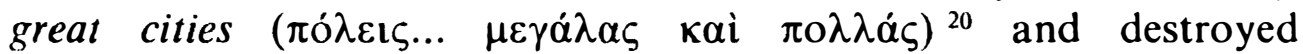

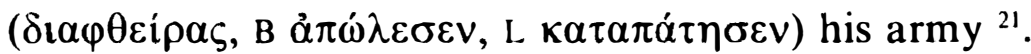

To his parallel to 13,7 Josephus appends (9.175a) a Rückverweis which represents the Syrian devastation of Israel in the time of Jehoahaz as the fulfillment of an earlier announcement by the prophet Elisha, see Ant. 9.90-92 (// 2 Kgs 8,10-12):

${ }^{15}$ Given the fact that $2 \mathrm{Kgs} 13,7 \mathrm{might}$ well be read as the direct continuation of 13,3, many scholars regard the intervening verses 13,4-6 as a secondary (Deuteronomistic) insertion, see the article of McCarthy cited in $\mathbf{n} .1$.

${ }^{16}$ On Josephus' tendency to "detheologize" in his retelling of the Bible's history in Ant., see L. H. Feldman, "Use, Authority, and Exegesis of Mikra in the Writings of Josephus, in M. J. Mulder and H. Sysling (eds.), Mikra: Text, Translation, Reading and Interpretation of the Hebrew Bible in Ancient Judaism and Early Christianity, Assen 1988, 455-518, 503-507.

${ }^{17}$ Here and in what follows I italicize those elements of Josephus' presentation which have no equivalent as such in the Biblical source(s).

18 This term is Josephus' precising substitute for the word "people" (MT עם, LXX $\lambda \alpha o ́ s)$ of $2 \mathrm{Kgs} 13,7$.

$192 \mathrm{Kgs} 13,7$ also speaks of the "ten chariots" left to Jehoahaz. By omitting this item, while conversely inserting a reference to the "very great" force Israel earlier possessed (see above in the text), Josephus accentuates the extent of Israelite losses at the hands of the Syrians.

${ }^{20}$ This un-Biblical indication continues Josephus' accentuation of the damage inflicted by the Syrians (see previous note). He likely found inspiration for this insertion in the prophecy of Elisha to Hazael, the future king of Syria, as cited by him in Ant. $9.91(/ / 2 \mathrm{Kgs} 8,12)$ "you will burn their strongest cities $(\pi \delta$ ó $\lambda \varepsilon 1 \zeta)$ " to which he introduces an explicit allusion in 9.175 (see below). Another inspiration for Josephus' mention of the Syrian conquest of Israelite "cities" here would be 2 Kgs 13,25 (// Ant. 9.184) which states, without the reader having been previously informed of the matter, that Joash of Israel regained from Ben-Hadad "the cities" which the latter' father Hazael had seized from Jehoahaz. Unlike the Bible then Josephus sets up this later item via his inserted reference to the Syrian seizure of Israelite cities during Jehoahaz' reign.

${ }^{21}$ Josephus leaves aside the imagery with which $2 \mathrm{Kgs} 13,7$ concludes, i.e. "(the king of Syria had made the Israelite forces) like the dust at threshing". 
These (misfortunes) the Israelite people ( $\delta \ldots \lambda \alpha$. $\ldots)^{22}$ suffered

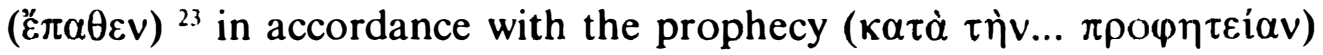
of Elisha ${ }^{24}$, who had foretold $(\pi \rho 0 \varepsilon i \pi \varepsilon)$ that Azaelos $(=$ Biblical

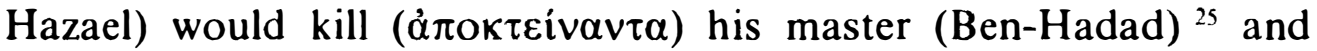

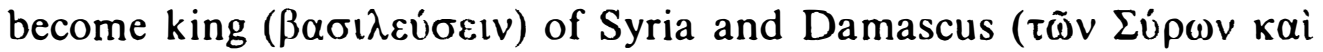
$\Delta \alpha \mu \alpha \sigma \kappa \eta \nu \tilde{\omega} v)^{26}$.

This addition is reflective of Josephus' tendency both to highlight the prophetic element of Biblical history and his understanding of the "truth" of prophecy to be above all a matter of making accurate predictions ${ }^{27}$.

Having presented his parallel to $2 \mathrm{Kgs} 13,3.7$ in 9.174-175a, Josephus now (9.175b) gives his amplified version of 13,4a: "Jehoahaz besought (LXX $\varepsilon \delta \varepsilon \eta \dot{\theta} \theta \eta$ ) [the face of] the Lord" This reads:

"But Joazos, being (helpless) before such great difficulties ${ }^{28}$, had

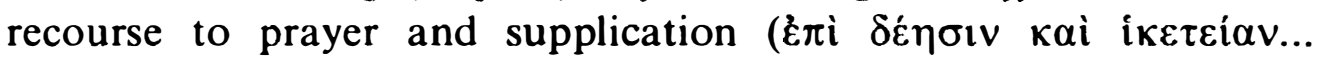

${ }^{22}$ The codices $S P$ read rather $\beta \alpha \sigma i \lambda \varepsilon u ́ s$.

${ }^{23}$ Note the verbal echo here of 9.90 where Elisha, speaking to Hazael, refers to "the great ills which the people ( $\delta \lambda \alpha \delta \delta)$ was about to suffer ( $\pi \dot{\alpha} \sigma \chi \varepsilon เ v)$..." because of him.

24 The above phrase "according to the prophecy of Elisha" recurs in $9.85(/ / 2$ Kgs 7,16): Elisha's prediction of the imminent fall of grain prices in besieged Samaria; 9.185: Joash regains territory lost to the Syrians by his father; here, just as in 9.175 , Josephus introduces a prophetic fulfillment notice which the source $(2 \mathrm{Kgs}$ $13,25)$ lacks. Comparable constructions featuring the name of some other Biblical prophet occur in Ant. 6.57 (Samuel); 7.214 (Nathan); 8.309 (Jehu) and 12.322 (Daniel). Compare the alternative phrase "according to the prophecy of God" in $6.136 ; 8.289$; 9.129 .

${ }^{25}$ In both the Bible $(2 \mathrm{Kgs} 8,10)$ and Josephus himself $(9.90)$ all Elisha actually predicts to Hazael is that king Ben-Hadad will, in fact, "die" of his current sickness. Here in 9.175 Josephus transposes into a prophecy by Elisha the action subsequently undertaken by Hazael who according to $2 \mathrm{Kgs} 8,15 / / 9.92$ took it upon himself to ensure the fulfillment of the prophet's announcement by suffocating the hapless BenHadad.

${ }^{26}$ Compare the wording of Elisha's announcement to Hazael in 9.92 (// $2 \mathrm{Kgs}$ $8,13 \mathrm{~b})$ "(he -Elisha- replied) that God had revealed to him that Azaelos was to be

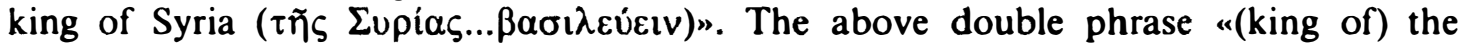
Syrians and the Damascenes" has its equivalent in the notice which Josephus attaches to his version of the encounter between Elisha and Hazael in 9.93 "(Hazael) was in great favour with the Syrians and the people of Damascus ( $\tau \tilde{\omega} \vee \Delta \alpha \mu \alpha \sigma \kappa \varepsilon v \tilde{\omega} v$ )"

${ }^{27}$ On these features of Josephus' "prophetology", see L. H. FELDMAN, "Prophets and Prophecy in Josephus", JTS 41 (1990) 386-422, 387-394 and 407-411. On the prophet Elisha in Josephus, see IDEM, “Josephus' Portrait of Elisha”, NT 36 (1994) 1-28.

28 With this inserted transitional phrase, Josephus continues to accentuate the gravity of Israel's plight, see above on his version of $2 \mathrm{Kgs} \mathrm{13,7} \mathrm{in} \mathrm{9.174.}$ 


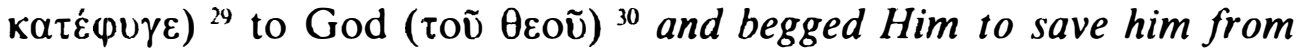
the hands of Azaelos ${ }^{31}$ and not suffer him to fall into his power ${ }^{32}$.

$2 \mathrm{Kgs} 13,4 \mathrm{~b}$ relates as the Lord's initial reaction to the king's appeal that he "hearkened to" Jehoahaz, doing so because «he saw the oppression of Israel, how the king of Syria oppressed them". 13,5 then continues:

Therefore the Lord gave Israel a savior (so MT מושיע, LXX

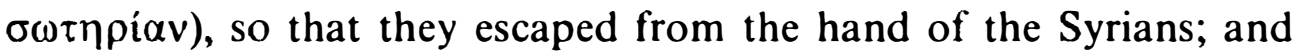
the people of Israel dwelt in their homes as formerly.

These notices, in turn, have a contentual parallel in the seemingly displaced indication of 13,23 (MT B)

But the Lord was gracious to them and had compassion on them, and he turned towards them because of his covenant ( $\operatorname{LXX} \delta 1 \alpha \theta \dot{\eta} \kappa \eta v$ ) with Abraham, Isaac, and Jacob and would not destroy (LXX $\delta 1 \alpha-$ $\varphi \theta \varepsilon i \tilde{\rho} \alpha)$ them nor has he cast them from his presence until now (these final two words are absent in $\mathrm{B}$ ) ${ }^{33}$.

${ }^{29}$ This is Josephus' only use of the above phrase "have recourse to prayer". Likewise the collocation of the above two terms for "appeal" occurs only here in his writings, cf. Ant. 10.242; 15.188 .

30 Josephus' reference to "(the) God" here substitutes for "the Lord" of $2 \mathrm{Kgs}$ 13,4. This substitution reflects his consistent tendency to avoid the latter term as a designation for the Deity, see C. T. BEGG, Josephus' Account of the Early Divided Monarchy (AJ 8,212-420), Leuven 1993, p. 45, n. 218. Josephus' formulation "prayer and supplication to God" likewise avoids the anthropomorphism of the phrase

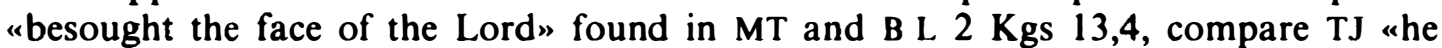
prayed before (קדם) the Lord".

${ }^{31}$ This formulation is likely inspired by the reference to the "hand of Syria" in 13,5 which the Israelites escape (so MT) or are brought out from under by the Lord (so LXX). Cf. also "the hand of Hazael king of Syria and the hand of Ben-Hadad" in 13,3 .

${ }^{32}$ With the above expansion of 2 Kgs 13,4a Josephus supplies a content for Jehoahaz' prayer.

${ }^{33}$ The notice on the Lord's compassion for Israel in 13,23 (MT B; L gives its parallel to this verse after 13,7) is introduced by the statement of 13,22 «Now Hazael king of Syria oppressed Israel all the days of Jehoahaz" which itself -oddlyfollows after the presentation of Jehoahaz' son Jehoash in 13,10-21 (in L what follows 13,22 is not 13,23, but an extended Sondergut sequence "and Hazael took Philistia from his [Jehoahaz'] hand, from the sea of the West to Aphek»; Josephus has no equivalent either to this item or to 13,22 ). 
Here again (see on 9.174 in relation to $2 \mathrm{Kgs} \mathrm{13,3.7)} \mathrm{Josephus}$ brings together (9.176) in a single sequence matter that in the source stands in separate contexts notwithstanding its contentual affinities. His version of $13,4 b-5 / / 13,23$ thus runs:

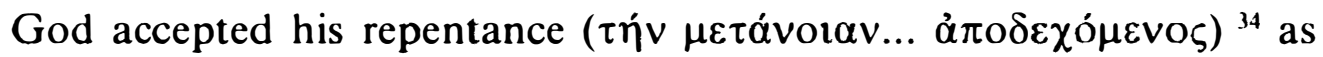

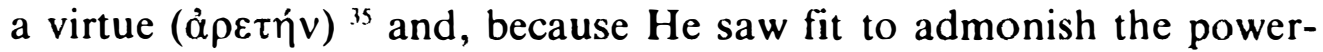

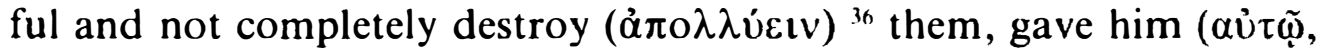

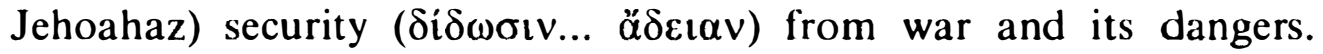
And so when the country had obtained peace, it was restored to its

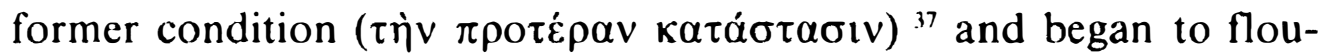
rish ${ }^{38}$.

${ }^{34}$ This is Josephus' only use of the phrase "accept repentance". His explicit mention of such repentance on Jehoahaz' part serves to further the historian's partial rehabilitation of this king whom he earlier described as "no imitator of his (reprobate) father", see 9.173b. On the theme of and terminology for "repentance" in Josephus in general, see A. SCHI.ATTER, Die Theologie des Judentums nach dem Bericht des Josefus, Gütersloh 1932, pp. 146-147; K. DiETrICH, Die Umkehr (Bekehrung und Busse) im Alten Testament und Judentum, Stuttgart 1936, pp. 309-313.

${ }^{35}$ The codices M S P read ápiotnv.

${ }^{36}$ This reference to God's seeing fit not to completely "destroy" the powerful was perhaps inspired by the words "he (God) would not destroy them" of 13,23, see above in the text. In any case, the didactic motivation which Josephus supplies ("because He saw fit... to admonish... and not completely destroy") here for God's intervention on Israel's behalf substitutes for those given in both 2 Kgs 13,4b: afor he saw the "oppression of Israel..." and 13,23: "because of his covenant (LXX $\delta 1 \alpha \theta \eta \kappa \eta v)$ with Abraham..."; Josephus' non-utilization of this last motivation is in line with his consistent tendency to avoid Biblical uses of the term $\delta \imath \alpha \theta \eta \kappa \eta n=$ ברית, see C. T. BEGG, Josephus' Account, pp. 100-101, n. 609.

${ }^{37}$ Josephus' one other use of the expression "former condition" is in Ant. 6.35.

${ }^{38}$ According to R. MARCUS, Josephus, VI, p. 95, n. d, Josephus' formulation in 9.176 (see above) represents an amplification of $2 \mathrm{Kgs} 13,23$ as opposed to 13,5. It seems, however, that the wording of 9.176 has also - and even more- been influenced by that of 13,4b-5. In particular its reference to God's "giving security" ( $\left.\delta i \delta \omega \sigma \imath{ }^{\prime} . . \alpha \not \delta \varepsilon \imath \alpha v\right)$ to Jehoahaz might be seen as Josephus' equivalent to the LXX reading in $13,5 \mathrm{a}$, i.e. $\varepsilon \delta \omega \kappa \varepsilon v . . . \sigma \omega \tau \eta \rho i \alpha v$. Note too that whereas 13,23 speaks only of God's solicitude for Israel as a whole, Josephus à la 13,4b ("he hearkened to him [Jehoahaz]") has the Deity "give security to him", i.e. Jehoahaz. Similarly, the mention of the country's being "restored to its former condition" echoes the phrase "the people of Israel dwelt in their homes as formerly" (MT literally "as yesterday and the day before") of $13,5 \mathrm{~b}$. Thus while 9.176 can be seen as a conflation of $13,4 \mathrm{~b}-$ 5 and 13,23 (with which the paragraph shares a reference to God's "not destroying" the afflicted, see n. 36), its verbal contacts are, pace Marcus, more with the former than the latter. 
Following the above description of Israel's revival in 9.176 (2 Kgs 13,4b-5.23), Josephus proceeds directly to narrate the death of Jehoahaz and the accession of his son Joash $(9.177 / / 2 \mathrm{Kgs}$ $13,9){ }^{39}$. In so doing, he simply passes over ${ }^{40}$ the source's intervening material. In particular, he leaves aside the statement of 13,6 that notwithstanding the Lord's intervention on their behalf "they (the Israelites) persisted in the sins of Jeroboam, just as the Asherah was allowed to remain in Samaria ${ }^{41}$. He likewise, in line with his invariable practice, makes no use of the standard source notice for Jehoahaz found in $13,8^{42}$.

\section{CONClusions}

By way of conclusion I shall now briefly sum up on my findings regarding the questions posed at the start of this essay. On the question of the textual affinities of Josephus' account of Jehoahaz, there is little, it seems, that can be said with any assurance. Josephus' reference to God's "giving security" to Jehoahaz in 9.176 might conceivably reflect the LXX "he gave salvation", as opposed to the MT reading "he gave a savior ${ }^{43}$ " in $2 \mathrm{Kgs} \mathrm{13,5}$. We also noted that like $\mathrm{L}$ and against MT and B, Josephus does not have a second, displaced, notice (MT B 13,23) on the Lord's delivery of Israel in Jehoahaz' time, parallel in content to $13,4 \mathrm{~b}-5$, following his account of Jehoahaz' son and successor Joash. This latter observation is, however, hardly conclusive evidence of Josephus' utilization of a Llike text of 2 Kings 13. Given the odd placement of 13,23 in MT and

${ }^{39}$ In Josephus' presentation this notice functions, in contrast to its Biblical parallel, not as a conclusion to the account of Jehohaz, but rather as an introduction to his presentation of Joash, 9.177-185.

${ }^{40}$ Recall that Josephus has already anticipated the content of 13,7 (the Syrian reduction of Israel's army), see 9.174.

${ }^{41}$ Josephus' non-utilization of this item is likely inspired by the consideration that to mention it would detract from Jehoahaz' repentance which he has just highlighted in 9.176 (just as it would point up the inefficacy of the divine admonition - the purpose for God's intervention on Israel's behalf according to Josephus, see n. 36).

${ }^{42}$ Presumably, Josephus' reason for omitting the royal source notices of Kings and Chronicles is that his presentation is based directly on the Bible, rather than its earlier sources.

${ }^{43}$ For speculations on the identity of this anonymous figure (e.g., Elisha), see the commentaries. 
$\mathrm{B}$, it is, on the contrary, quite possible that Josephus, finding that notice in its MT/B position in his text of 2 Kings 13, shifted it, on his own initiative, to an earlier (and more obviously appropriate) point in his presentation, at the same conflating it with the related data of $13,4 b-5$ (see note 38$)^{44}$.

More definite conclusions are possible regarding Josephus' handling of the various problems presented by the Biblical story of Jehoahaz. He resolves the chronological discrepancy between $2 \mathrm{Kgs}$ 13,1 and 10 by having Jehoahaz accede in the twenty-first (rather than twenty-third) year of Joash of Judah (9.173). Whereas the source account in its current, redacted form separates, and duplicates, items that contentually belong together, i.e. Israel's oppression by the Syrians (13,3 and 7) and the Lord's saving intervention (13,4b-5 and 23), Josephus, in both instances, reduces the Biblical data to a single statement (see 9.174 and 9.176 , respectively). Thereby, he generates a tighter, more coherent presentation of Jehoahaz' reign, a characteristic still further accentuated by his omission of the material of 13,6 (Israel's persistence in apostasy) and 8 (source notice for Jehoahaz).

As to Josephus' personal contributions in his Jehoahaz story, we noted that he somewhat accentuates the magnitude of the losses inflicted on Israel by the Syrians (see 9.174; compare $2 \mathrm{Kgs} \mathrm{13,3.7).}$ In so doing he introduces a notice about the Syrian seizure of Israelite cities which serves to set up the subsequent notice of $2 \mathrm{Kgs}$ 13,25 (9.184) about Joash regaining cities lost by his father to Hazael. Conversely, Josephus also plays up the extent of Israel's divinely effected revival, see the concluding reference in 9.176 to the country's «beginning to flourish" once again which has no equivalent as such in either $2 \mathrm{Kgs} 13,4 \mathrm{~b}-5$ or 13,23 . The "fulfillment notice" (9.175a) which Josephus appends to his account of Israel's subjugation by Syria $(9.174 / / 2 \mathrm{Kgs} \mathrm{13,3.7)}$ underscores the status of

\footnotetext{
${ }^{44}$ In addition, the following observations militate against taking the agreement between Josephus and $\mathrm{L}$ regarding the placement of the content of $2 \mathrm{Kgs} 13,23$ (MT, B) as solid evidence of his dependence on a (proto-) $\mathrm{L}$ text of 2 Kings 13:1) In $\mathrm{L}$ the duplication between $13,4 \mathrm{~b}-5$ and 13,23 (MT, B) is retained, the latter verse being cited after 13,7; Josephus, by contrast, seems to conflate both verses into a single statement in 9.176 (see n. 38). 2) Josephus has no equivalent to $2 \mathrm{Kgs} 13,22$ with its displaced reference to the Syrian oppression of Israel in Jehoahaz' days which in L stands at the same point as it does in MT and B. 3) Josephus likewise gives no indication of familiarity with the $L$ plus appended to 13,22 , i.e. "And Hazael took Philistia from his (Jehoahaz') hand, from the sea of the West to Aphek".
} 
Elisha as a true prophet, i.e. one whose prediction to Hazael (9.91 $\left./ / 2 \mathrm{Kg},{ }^{2}, 12\right)$ now comes to realization. Of all Josephus' retouchings of the Biblical story, the most notable is, however, his partial rehabilitation of the figure of Jehoahaz. In the Bible Jehoahaz figures as just another bad Israelite king. Josephus, while not denying that he continued his predecessors' cultic misdeeds, also represents (9.173) Jehoahaz as "no imitator" of his father Jehu who ended up "careless of his duties toward the Deity and contemptuous of holiness and the laws" (9.160). He further highlights Jehoahaz' positive stature by spelling out the content of his prayer $(9.175 \mathrm{~b} / / 2 \mathrm{Kgs}$ 13.4a) and by having God credit him with actual "repentance» (9.176). The rationale for Josephus' modification of the source treatment of Jehoahaz is not immediately apparent. Perhaps, it is intended simply to make more credible the Deity's eventual heeding the appeal (see $2 \mathrm{Kgs} \mathrm{13,4)}$ of one who is introduced in so unqualifiedly negative terms in $13,2{ }^{45}$.

Ant. 9.173-176 is, of course, only a minuscule portion of Josephus' Biblical paraphrase. Nonetheless, as I hope to have shown in the foregoing discussion, it does attest both to the historian's sensitivity to the problems posed by his source and his interest in imparting a personal stamp to his retelling of the Bible's story - even in the case of a decidedly minor character like Jehoahaz.

${ }^{45}$ It might be mentioned here that also elsewhere one finds Josephus improving the image of various reprobate Biblical kings, e. g., Joash of Israel (see Ant. 9.177 and compare $2 \mathrm{Kgs} \mathrm{13,11)}$ and Jehoiachin (see Ant. 10.99 and compare $2 \mathrm{Kgs} 24,9 / / 2 \mathrm{Chr}$ $36,9 \mathrm{~b})$. In the case of both these other kings Josephus' favorable comments concerning them may, however, reflect traditions circulating at his time since the Rabbinic material does preserve comparable positive remarks about both of them. By contrast, Josephus seems to stand alone in his effort at (partial) rehabilitation of Jehoahaz. (I am grateful to Prof. L. H. Feldman for bringing this point to my attention). 


\section{RESUMEN}

La breve crónica acerca del rey de Israel Joacaz en $2 \operatorname{Re} 13,1-9(+22-23)$ presenta varios problemas: textual, cronológico, de redacción y de composición. Este trabajo ofrece una comparación detallada del relato de Josefo en Ant. 9.173-176 con su fuente biblica. Esta comparación tiene como objetivo considerar qué puede ser determinado en lo que se refiere, por ejemplo, a la(-s) forma(-s) de texto de $2 \operatorname{Re} 13$ a la(-s) que Josefo tuvo acceso, al tratamiento que Josefo da a los problemas presentados por el relato bíblico y a las aportaciones personales de Josefo al narrar de nuevo la historia de Joacaz.

\section{SUMMARY}

The summary Biblical treatment of king Jehoahaz of Israel in 2 Kgs 13,1-9 (+ 2223) poses a variety of problems: textual, chronological, redactional and compositional. This essay provides a detailed comparison of Josephus' account of Jehoahaz in Ant. 9.173-176 with its Biblical source. The comparison aims to see what can be determined concerning, e.g., the text- form(-s) of $2 \mathrm{Kgs} 13$ available to Josephus, his handling of the problems presented by the Biblical treatment of Jehoahaz and his own personal contributions in his retelling of that king's story. 